\title{
東京都心部の地下空間への氾濫水の流入危険度 とトンネル内の浸水域拡大過程に関する検討

\author{
NUMERICAL ANALYSIS OF INUNDATION \\ IN UNDERGROUND SPACE AND SUBWAY TUNNEL IN TOKYO
}

\author{
関根正人 ${ }^{1}$ - 関根貴広 ${ }^{2}$ \\ Masato SEKINE ${ }^{1}$ and Takahiro SEKINE ${ }^{2}$ \\ ${ }^{1}$ 正会員 工博 早稲田大学理工学術院教授（† 169-8555 東京都新宿区大久保 3-4-1) \\ 2 学生会員 早稲田大学大学院創造理工学研究科（同上）
}

\begin{abstract}
Recently, localized torrential rain occurs frequently. In order to clarify inundation risk of Tokyo metropolitan area, numerical simulation of urban inundation was conducted. In this study, following three investigations were conducted. First, numerical simulation of inundation event which occurred on June 29, 2014 was carried out by using the actual rain data which was obtained by X-band MP radar. Based on this result, validity of this prediction technique was confirmed. Another investigation was done to find out the inundation risk of each entrance gate to judge whether the inundated water on road could flow into the space of subway stations through it. We specified such entrances gate. And then, we attempted to understand the expanding process of water in the subway tunnel by another numerical computation.
\end{abstract}

Key words : urban inundation, localized torrential rain, underground space, subway tunnel

\section{1. 序論}

近年，地球規模で進行する気象の極端化により，東京 をはじめとした大都市では設計強度を大きく超える豪雨 が発生している.今後は，豪雨時に予想される浸水の規 模ならびにプロセスを可能な限り正確に予測し ${ }^{1)}$ ，その 結果を被害軽減対策に反映させていく必要がある.さら に，いざという時に有益な情報を提供するリアルタイム の浸水予報の技術を開発・実用化していくこともあわせ て重要である。

東京都心部が豪雨に襲われたときに深刻な被害が懸念 されるのが地下空間である．著者らは，東京丸の内にあ る大規模地下空間 ${ }^{2)}$ や地下鉄溜池山王駅さらには新宿サ ブナードなどを対象に，地上の内水汇濫と連動した浸水 予測を行ってきた．都心部の地下には地下鉄が縦横に延 びており，地下鉄駅と道路面をつなぐ連絡口は 1,000 を 超える.もし地上に深刻な浸水被害が発生すると, 氾濫 水がこれらの連絡口を通じて流れ込み，地下鉄駅が浸水 するおそれがある。地下鉄駅を含む地下空間の浸水を防 ぐための対策として，近年，連絡口に止水板や防水屝が 取り付けられるようにする工事が進んでいる.ところが, その多くが手動で設置するものであるため, 設置のタイ
ミングに遅れが生じることがないとは言えず，汇濫水が 浸入する危険を 0 にすることは不可能に近い. ただし, 汇濫水が流入する可能性のある連絡口を予め特定してお ければ，効果的な対策を講じることができる.

本研究では，首都機能が集中する東京都心部に相当す る「芝浦ならびに三河島下水道処理区」からなる広大な エリアを対象に検討を行った. ここでは，リアルタイム 浸水予報の実現を目指した検討のひとつとして，国土交 通省の X バンドMP レーダによって観測された高空間 分解能 (約 $250 \mathrm{~m}$ メッシュ) のXRAIN のデータを用い, これを入力值とした浸水計算を行った，さらに，その計 算結果を当時の画像データなどとの比較・検討を行った. これにより，実降雨データを入力值とした予測計算手法 の妥当性を検証することを目指した，第二に，著者らの これまでの検討と同様に 2005 年に東京都杉並区で観測 された豪雨 (杉並豪雨と呼ぶ) を対象とした浸水予測の 結果に基づき, 都心部に位置する地下鉄駅 (都営地下鉄 を除く）を対象に，地上で生じる浸水のプロセスやその 規模の評価を行った.さらに，その結果を踏まえて，こ の区域内に存在する地下鉄駅へとつながるすべての連絡 口を対象に，道路から汇濫水が流れ込む可能性について 精査した. また，汇濫水が地下鉄のトンネルまで到達し 
た場合を想定して，その水が実在するトンネル内をどの ようなプロセスを経て広がっていくのかについて理解す るために，数值計算を通じた検討を行った.

既往の研究のうち本研究と最も関連性が高いのは, 荒 川の堤防決壊を想定し, その際の地下鉄トンネル内の浸 水解析を行った池内らの研究 ${ }^{3)}$ を挙げることができる.

\section{2. 解析の概要}

\section{（1）対象区域の特徵}

本研究で対象とするのは, 東京都下水道局の芝浦処理 区と三河島処理区をあわせたエリアである。ここには， $\mathrm{JR}$ 山手線内全域が含まれている。 この区域内の地上（道 路上）の標高の違いを色分けして示したのが図-1 のコ ンター図である.ここでは, $1 \mathrm{~m}$ メッシュ毎に計測され たLPデータを用いて標高を評価した. この区域内には 千代田区をはじめ 12 の行政区が含まれ，その地表の総 面積は約 $104 \mathrm{~km}^{2}$ である. 対象区域の東側と北側には隅 田川, 南側には目黒川が流れており, 西側の境界はJR 山手線上とほぼ一致するように設定されている. 下水道 に関しては，対象区域の境界と上記のふたつの処理区の 外縁線とが一致している，そこで，境界線をまたぐよう な水の流れは, 地上ならびに下水道内ともにないと考え てよい. なお，南北に接する二つの処理区の間には，ほ ぼ東西に神田川が流れており，下水道内の水の一部は雨 水吐を通じて，この神田川に流出寸るようになってい る. また, 南側の芝浦処理区内には渋谷川 (下流側で古 川と名称を変える) が延びており，ここにも下水道から の水が流れ込む. さらには，隅田川に面する東側の低地 には多くのポンプ所や水再生センターがあり, 下水道内 の雨水の多くはこれらの施設を通じてポンプ排水されて いる. この区域の地形的な特徵として, 東側から西側に 向かって標高が高くなる傾向にあり, 谷地形が西側に向 かって入り込んでいる. また，この谷筋に沿って幹線道 路が延びており, その道路面下には幹線下水道が整備さ れているものの, 深刻な浸水が生じることが懸念される.

このエリアの地下には，地下鉄の全 13 路線が縦横に 延び，100を超える地下鉄駅が存在する．地上で深刻な 浸水が生じると, その汇濫水が連絡口から流入して地下 浸水が発生することが懸念される.

\section{(2) 対象降雨}

本研究では，二種類の降雨データに対してそれぞれ浸 水予測計算を行った. 第一は, 2014 年 6 月 29 日に東 京都 23 区全域で発生した集中豪雨であり，その際に計 測された害降雨データを用い, 当時の浸水状況の再現計 算を行った.この結果については3.で説明する. 第二は, 2005 年9月に東京都杉並区下井草て観測された豪雨 (杉 並豪雨) のデータであり，これを用いた計算によって 4. で説明する地下鉄駅連絡口からの氾濫水の流入危険度

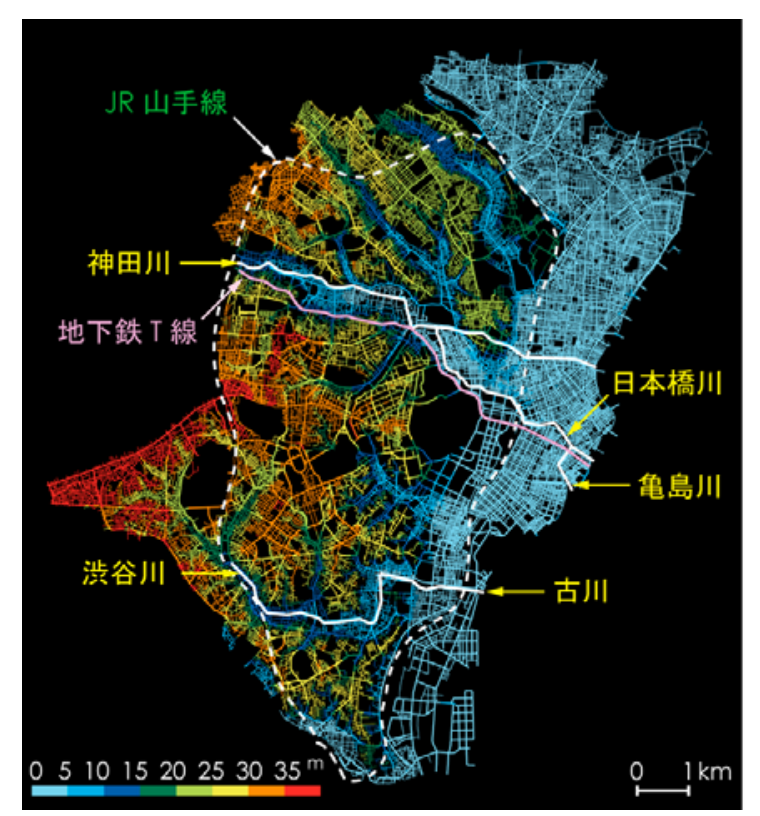

図 -1 検討対象区域の概要と地上標高コンター図

評価を行った.

まず，2014 年 6 月 29 日の豪雨は短時間ながら極め て高強度であり, 対象区域には 15:45〜 16:45 の 60 分 間にわたって降り続いた。 ここでは, 国土交通省のX バンドMP レーダによる高精密降雨データ (XRAIN) を 用いた．これは，約 $250 \mathrm{~m}$ 毎のメッシュに対する降雨量 が 1 分間隔で得られており, これまでにない高分解能を 有するデータである.ここでは, 対象区域内の各メッシュ 毎の降雨量を時々刻々変化するものとして与え, 17:15 までの 90 分間にわたる浸水計算を行った.

一方，杉並豪雨は東京都 23 区内でこれまでに記録さ れている中でも最大級のものである. 下水道の設計強度 である $50 \mathrm{~mm} / \mathrm{h}$ 以下の降雨の時間帯を除いて比較する と, この雨は, 2000 年に名古屋で発生した東海豪雨に 匹敵する豪雨と言える. 総雨量 $263 \mathrm{~mm}$, 最大時間雨量 $112 \mathrm{~mm}$ であり, 降雨開始 50 分後から 140 分間にわたっ て $50 \mathrm{~mm} / \mathrm{h}$ を超える高強度の雨が降り続いた. 本検討 では, 当時のハイエトグラフに基づき, 対象区域内にこ の雨が一様に降るものとして浸水予測計算を行った.

\section{（3）予測計算手法}

計算には，第一著者による浸水予測手法 ${ }^{1)}$ を用いた. この解析手法は「地上・下水道・都市河川」の水の流れ を一体的に解くものであり, 解析に当たっては次のよう な詳細なデータベースを作成した上で，これを忠実に反 映させた計算を行った. すなわち，(1) 路地に到るまで のすべての道路ネットワークの情報，(2) 枝管路まで含 めた東京都の下水道ネットワークの情報, (3) 神田川・ 日本橋川・亀島川, 渋谷川・古川といった都市河川の情 報や，(4) 建ぺ率や容積率に代表される街区の土地利 用状況に関する情報などであり, 都市インフラに関わる 
ほとんどすべての情報が考慮されている，このほか，道 路と下水道とをつなぐ雨水ますや，下水道と都市河川を 結ぶ雨水吐，ポンプ所や水再生センターなどについての 情報も現実に即して忠実に考慮され，その機能が現実の とおりに発揮されるように留意した. これにより考え得 る限りの精緻な浸水予測が行われた。

対象区域内には，神田川とその支川ならびに渋谷川・ 古川という二水系の都市河川が流れている. これらは雨 水吐を通じて下水道とつながっている. そのため, 都市 の浸水予測を行う際には, 河川内の流れ (洪水流)につ いてもあわせて解く必要がある. 河川の水位が上昇して, 下水道末端に位置する雨水吐の天端の高さを超えるよう になると, 河川から下水道への逆流が生じることもあり 得る. この予測計算手法では, 雨水吐につながる下水管 の上流端での全水頭と下流端における河川水位との関係 から, 雨水吐を通じた下水道一河川間の流量を計算した. 河川から下水道に向かう逆流についても忠実に再現でき るようになっている. 河川における流れの計算は，川幅 や河床高・護岸天端高などの実デー夕を踏まえて, 一次 元不定流計算を行った．渋谷川・古川は，その上流端に つながる幹線下水道も含めて, その全流域が対象区域内 に位置する. また，神田川はその上流域がこの西側に広 がっているが，ここではこの上流域には雨が降っていな いものとして計算を行った．ただし，神田川ならびにそ の支川の流れについては，源流である上流端から河口ま で計算するようにした．参考までに，この上流域におけ る同様の計算は寸でに報告済み ${ }^{4)}$ であり, 現時点で両者 を結合し, 神田川流域全体を一括して予測計算できるよ うになっている. しかし, コンピュータの記憶容量なら びにその演算速度の関係から，ここではあえて全域を一 括して計算することはしなかった。

\section{2014 年 6 月に発生した豪雨時の浸水プロセス}

本章では, 2014 年 6 月 29 日に発生した豪雨時の再現 計算の結果について説明する. 図 -2 に数值予測計算の 結果を示寸.この図には, 当日の 16:00, 16:15, 16:30 の3 つの時刻における結果がまとめられている. 継続時 間の短い豪雨であったことから, 深刻な浸水は報告され ておらず, 数值予測計算の結果も同様であった. このた め, 紙面の関係で浸水深について詳しく述べることはせ ず，その一部をふれるにとどめた。

図-2の上段には XRAINによる各時刻における降雨 の面的な分布を示した. この図は，それぞれの時刻に道 路上の各地点に降ったとされる雨の強さを, 時間雨量 に換算した上で，それを異なる色で塗り分けて示した. XRAINによる降雨強度のデータは, 対象区域全域を網 羅するようにとられており, 各メッシュの大きさは東西 方向に $283 \mathrm{~m}$, 南北方向に $231 \mathrm{~m}$ である. そこで, 道路 計算点の各々が位置するメッシュを判別し，そのメッ
シュに対して得られた降雨強度の雨がその道路上に降る ものとした. 図中に紫色で示されるエリアには時間雨 量 $100 \mathrm{~mm}$ を超える極めて強い雨が降っていたことにな る. また, 紫色・赤色・オレンジ色で塗られたエリアで は, 下水道の設計強度である $50 \mathrm{~mm} / \mathrm{h}$ を超える雨が降つ ていたことを表す。

また，図-2の下段には下水道満管率のコンター図を 示した. 図中に赤色で塗られた管路が満管状態の流れに なっていることを意味する. 満管状態の下水管内では水 圧が高くなっており，そこに到る直前に雨水ますやマン ホールから地上に向かって水が溢れ出ることがある.

図-3は，渋谷駅周辺に注目して計算の結果をまとめ たものである. 図-3(a) の11は「スクランブル交差点」 として知られている地点である. この地点から(2)の方向 にJR 山手線の下をくぐるよう延びるアンダーパスが延 びている. NHKによる当時の画像を解析すると，16:30 の時点でこの(2)の地点の浸水深が $0.2 \mathrm{~m}$ 程度と判断され た.これに対して, 同地点における浸水深ハイドログラ フは図-3(c) 中の青色の実線のようになり，この值は同 時刻での計算結果とほぼ一致する. また, $16: 30$ の時点で, 図-3(b) 中の(3)に当たるスクランブル交差点付近, なら びに(4)に当たるバスターミナル前では，マンホールの蓋 に空けられた穴から空気混じりの水が吹き出ていたこと がわかっている. 同時刻に(4)のバスターミナル前で撮影 された写真を図-3(e) に示す. 一方, 地点(3)(4)に位置す るマンホール点での下水道満管率のハイドログラフを示 したのが図-3(d) である.これらのマンホール地点では 16:30 の直前の 10 分間ほどの間に雨水が急速に集中し, 満管状態の流れとなっていたことが確認された.このよ うに, 本予測手法による計算により, 実現象がかなり良 好に再現できていると判断される. 今後, さらに多くの 観測情報が得られれば、それとの照合を通じて予測手法 のさらなる信頼性の検証が可能となる.

\section{4. 地下鉄駅連絡口からの氾濫水の流入危険性}

ここでは，道路上の氾濫水が連絡口を通じて地下鉄駅 （都営地下鉄の駅を除く）構内に流れ込む可能性に関わ る検討結果について説明する. この検討には，2005 年 9 月に杉並区下井草で観測された豪雨データを用いた. 図-4(a)には, この豪雨により浸水が最も深刻な状態と なる時点 (降雨開始 140 分後) の道路上浸水深のコン ター図を示した. この図より, 図-1に水色で表示され た標高の比較的低い東側のエリアにおいて，特に大きな 浸水が生じており, 地点によっては浸水深が $1 \mathrm{~m}$ を超え ることが確認された。

地上から地下鉄駅構内につながる階段の上部に位置す る連絡口毎の氾濫水流入危険度の評価は, 2014 年 9 月 の時点での各連絡口に関わる詳細なデータに基づいて行 われた. 具体的には, 各連絡口がごの道路交差点に面し 

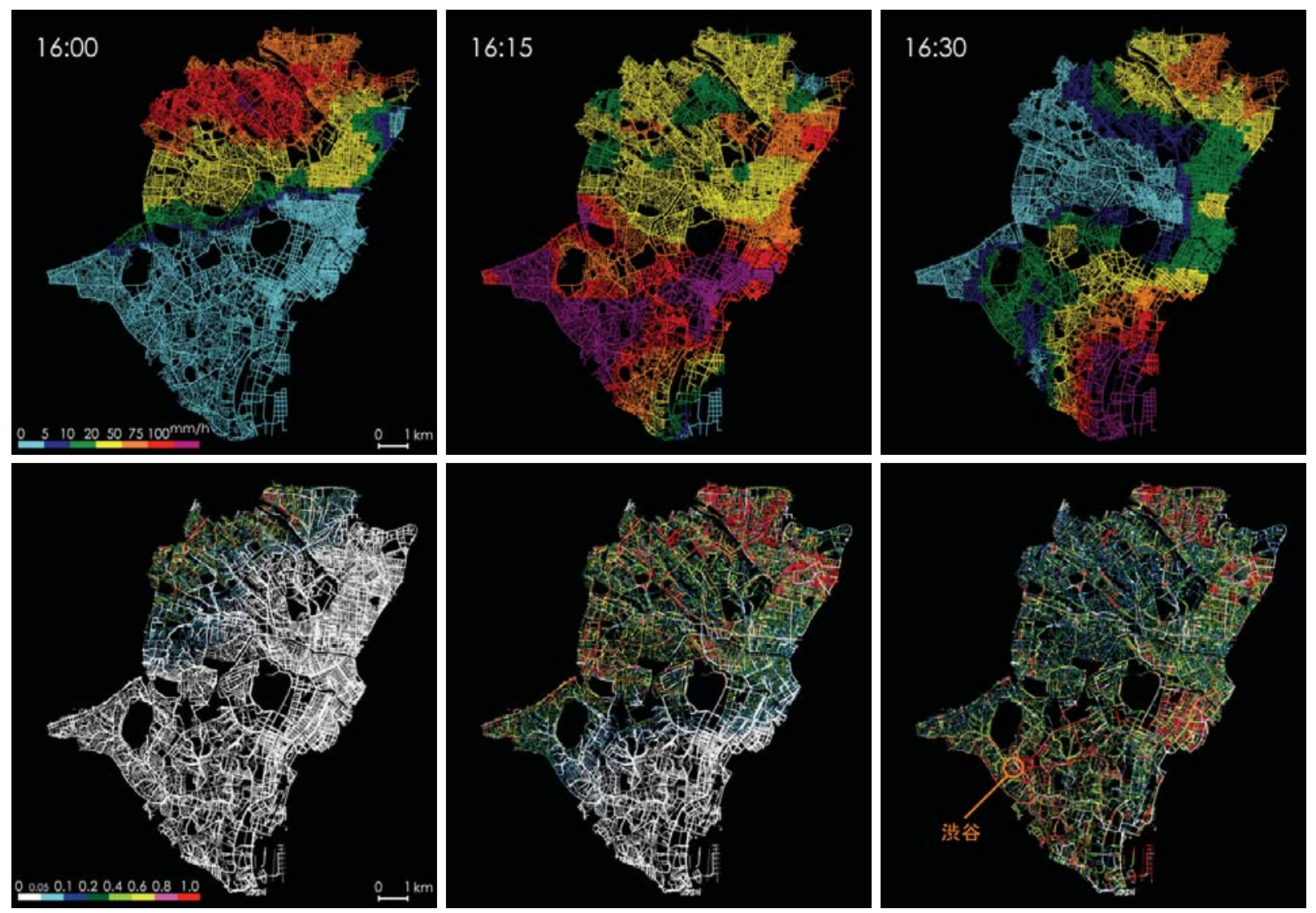

図 -2 道路上の降雨強度・下水道満管率のコンター図 : 上段が降雨強度, 下段が下水道満管率の結果を表す.
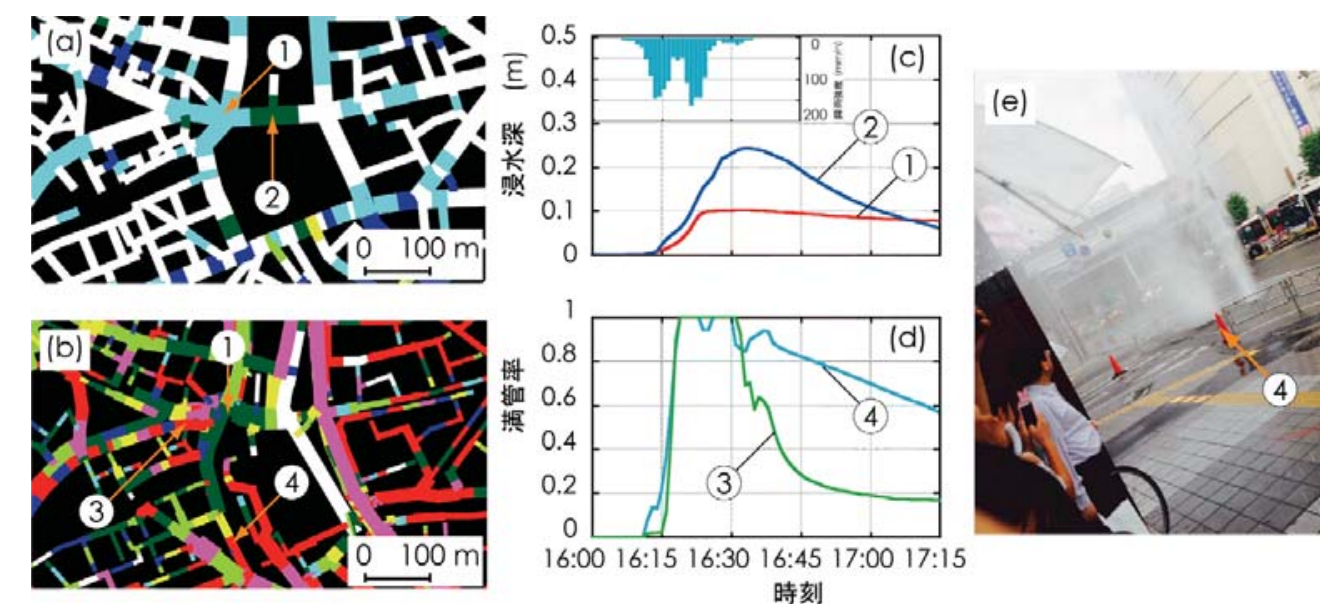

時刻

図 -3 渋谷駅周辺の検討結果 : (a) 道路上の浸水深コンター図の拡大図 (16:30 時点), (b) 下水道の満管率コンター図の拡 大図 (同上), (c) 地点(1)(2)の浸水深ハイドログラフ, (d) 地点(3)(4)のマンホールにおける下水道満管率のハイドロ グラフ, (e) 地点(4)の当時の浸水状況を撮影した画像 (16:30 時点, NHK を通じて視聴者より提供 ).

ているかを調べ，浸水予測結果を踏まえてその点で生じ ると計算された最大の浸水深と, 各連絡口の入口高さと を比較することにより，これを判定した．ただし，連絡 口には寸でに止水板を設置するための工事が完了してい る点も多い，そのため，実際に準備されている止水板の 高さについての情報を踏まえ, もし事前に止水板の設置 が完了しているとすればその連絡口では氾濫水の流入を 防げるのか，といった検討もあわせて行った.

図-4(b) は，各連絡口を通じて道路上の汇濫水が流入 寸る危険性についての検討結果をまとめたものである.
図中に示された四色の印が連絡口のある地点を表し， その色によって以下の 4 つの状態のいずれに当たるかが 判別できるようになっている. なお，地下鉄駅構内に隣 接する建物内部からアクセスでき, 道路に面していない 連絡口やエレベーターについては，この検討の対象外と した. その結果, 対象区域内には合計 93 の駅があり, そこにつながる連絡口の総数は776 箇所であった. 詳 細に検討したところ, 「止水板がない状態で氾濫水が流 入する連絡口」(黄色の印) が 288 箇所, 「止水板が未 整備でしかも水の流入が生じる連絡口」（オレンジ色の○ 

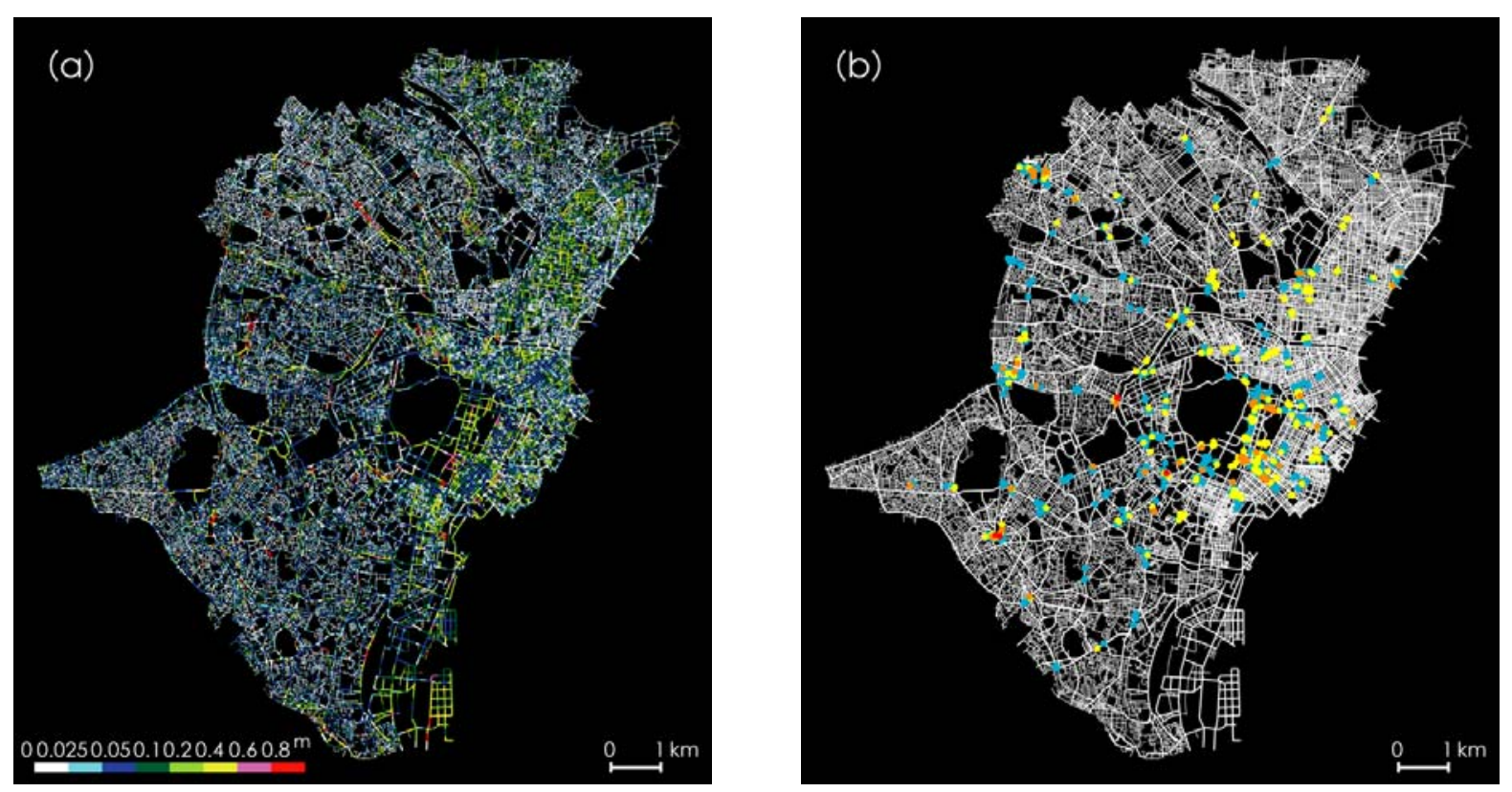

図 -4 豪雨による地上の浸水状況と連絡口の汇濫水流入に関わる検討結果 : (a) 道路上の浸水深コンター図 (降雨開始 140 分後の時点), (b) 各連絡口の汇濫水流入危険度の判定結果. 黄色のの印: 止水板を取り付けない状態で汇濫水が流入 する連絡口，オレンジ色の○印：止水板が未整備でしかも水の流入が生じる連絡口，赤色の○印 : 準備されている止水板 を遅れなく設置したとしても水が流入する連絡口，水色の○印 : 汇濫水が流入しないと判断された連絡口.

印 ) が 54 箇所, 「準備されている止水板の高さが不足す るため，これを遅れなく設置したとしても汇濫水の流入 を防ぎきれない連絡口」（赤色の○印）が 4 箇所,「水が 流入することはないと判断された連絡口」（水色の○印） が 430 箇所であり，「止水板を設置することで流入を防 げる連絡口」が 230 箇所という結果になった。

この検討結果から，(1)止水板が設置されない状態で は，連絡口の約 $37 \%$ にあたる箇所から氾濫水が流入す る，(2)ただし，整備されている止水板を遅れなく設置 することができれば，ほとんどの連絡口において汇濫水 の流入を防ぐことができる，ことなどが明らかになった。 調査時点では止水板の高さが不足していた連絡口 4 箇所 については，速やかな対処が望まれる．また，止水板が 未整備である連絡口についても直ちに対策を講じる必要 がある.ここで, 一例としてこのうちの H 駅について 述べると，止水板を事前に設置しておかないと合計 15 箇所の連絡口から汇濫水が流入する可能性がある. 複数 の連絡口から汇濫水が流入すると急激に浸水域が広がる とともに, 複雑な浸水拡大プロセスとなる恐れがある. ただし，この 15 箇所の連絡口から流入が始まる時刻と その流量には差異があることから，対処に当たり優先順 位をつけることができ，この順に止水板を設置していけ ばよいということになる. 事前の検討により，このよう な科学的根拠を得ておくことが重要である.

\section{5. 地下鉄トンネル内の浸水拡大プロセス}

本研究では，地下鉄 $\mathrm{T}$ 線を具体的な検討対象として, トンネル内に入り込んだ汇監水が広がるプロセスについ
て検討した.ここでは,これついて説明する.この路線は, 東京都 23 区の西部と千葉県北西部を結んでおり，その 総延長は約 $30 \mathrm{~km}$ である. このうち, 途中の約 $17 \mathrm{~km}$ 分 が地下トンネル区間に当たる.このトンネル内の水の流 れを, 下水道内のものと同様の手法を用いて, 一次元非 定常流れとして数值計算した. ここでは, 計算点を $10 \mathrm{~m}$ 間隔に設定した.この区間のトンネルは区間により矩形 あるいは円形断面となっている。 そこで，円形断面区間 に関しては，面積の等価な矩形断面に置き換えて解いて いる．実際のトンネルは東向きと西向きの軌道が異なる 位置に敷設されている区間と, 同一の横断面内に両方が 存在する区間とがある. 前者に関しては，方向別に独立 したトンネルとし，水深ならびに流速をそれぞれ計算し た. 一方，後者では，両方の軌道に対する值が同一とな るため, そのような計算方法によりその流れを解いた. 本計算では，図 -5 中の三地点 $\mathrm{A} \sim \mathrm{C}$ にそれぞれ $1 \mathrm{~m}^{3} /$ $\mathrm{s}, 0.5 \mathrm{~m}^{3} / \mathrm{s}, 1 \mathrm{~m}^{3} / \mathrm{s}$ の流量の水が同時に流入し続けると 想定し，この状態が 24 時間にわたるとした. なお，こ の流入地点は，いずれもプラットホームにつながる階段 のある位置にとられており，その流量はこれまでの浸水 予測計算の結果などを踏まえて決定した。連絡口の幅を $2 \mathrm{~m}$, 越流水深を $0.3 \mathrm{~m}$ とすると $1 \mathrm{~m}^{3} / \mathrm{s}$ 程度の流量となる ことから，ここではこの程度の流入を想定したことにな る.それぞれの地点は, 神田川, 日本橋川, 隅田川に近 い位置にあり，河川からの汇濫が生じた場合にはこれよ りもさらに大きな規模の流入となる可能性がある.

図 -5には，氾濫水の流入開始から 120，300，960， 1200 分後の水面形が示されている. これはあくまでも ひとつの計算事例にすぎないが，このような計算を行う 


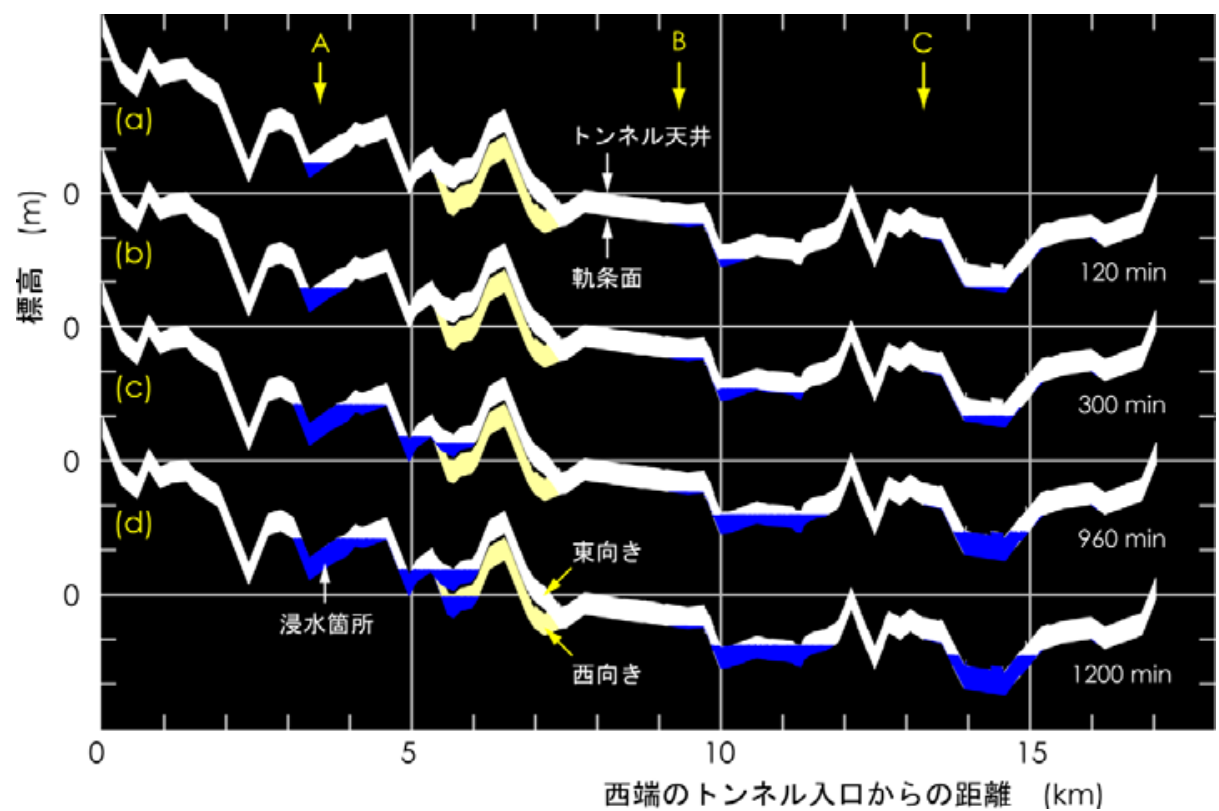

図 -5 路線上の水面形の縱断図：上から順に氾濫水の流入開始から 120，300，960，1200 分後の状態を表す. 各縦断図 の原点は標高 $0 \mathrm{~m}$ を示し, 縦軸の 1 目盛が高低差 $10 \mathrm{~m}$ に相当する. 黄色の矢印は氾濫水が流入するとした地点, 青色，黄色で塗りつぶされた箇所が浸水している区間，トンネルの西向き路線をそれぞれ表す.

ことによって，トンネル内で生じる流入水の流動の傾向 を窥い知ることができる．なお，ここでは三地点からの 水の流入を想定したが，計算時間内に各々から流入した 水がトンネル内で出遭うことはなかった。 このため, そ れぞれを独立した事象として解釈することが可能であ る. トンネル内の水は当然ながら水位の低い地点を目指 して流れるが，トンネルには峠と谷に相当する凹凸が存 在するため, その冠水範囲の拡大は必ずしも連続的で単 純なものではないことがわかる. それぞれの峠の部分に 遮られるためであり，これを超えられるまではその上流 側で水深が増大していく時間がある. ただし，この流入 がさらに長時間にわたって継続すると, 範囲の拡大を妨 げていた峠を超えて水が流れるようになるため, やがて はトンネル全体が水没する事態にまで到ると考えられ る. このような情報は, 移動車両をどの駅で停車させる と利用客の避難上望ましいのか，車両まで水没すること は避けるにはどの場所に停車させるとよいか，といった 点を考える上での根拠のひとつとなる.

\section{6. 結論}

本研究では, 東京都心部に位置する広い範囲を対象と して，浸水の数值予測計算を行った. また，その結果を 踏まえて, 区域内に位置する全ての地下鉄駅に対して, そこにつながる連絡口からの汇濫水の流入危険性の判定 を行った. これにより, どの連絡口から水が浸入する可 能性が高いかが明らかになった．なお，この情報はすで に管理者に伝えられ，浸水被害軽減対策に活かされてい る. 最後に, 実際の地下鉄のトンネルを対象として, ト ンネル内の流入水の流動についての数值解析を行った.
その結果，トンネル内に峠のような凸地形があることが 重要であり, これがトンネル内の水の流れを大きく支配 することが確認された.

謝辞 : 本研究の一部は東京地下鉄株式会社との共同研究の成 果であり, デー夕の提供を含めて多大な協力をいただいた. 河川ならびに下水道に関する情報は東京都建設局ならびに下 水道局から，XRAIN による降雨デー夕は国土交通省からそれ ぞれ提供を受けた。 また，2014 年 6 月 29 日の豪雨時の浸水 状況に関しては，NHK の担当者から画像の提供を受けるなど ご協力いただいた. 本研究の遂行に当たり, 中沢優也君・中 村光宏君・鈴木昌宏君 (当時, 早稲田大学学部学生) の協力 を得た。ここに記して感謝申し上げたい．

\section{参考文献}

1) 関根正人 : 住宅密集地域を抱える東京都心部を対象とした 集中豪雨による内水氾濫に関する数值解析, 土木学会論文 集 B1( 水工学), Vol.67, No.2, 70-85, 2011.

2) 関根正人 - 古木雄 - 関根貴広 : 東京都心部の内水汇濫と大 規模地下空間浸水の危険度に関的る数值解析, 土木学会論 文集 B1( 水工学), Vol.71, No.4, I_1435-I_1440，2015.

3) 池内幸司 - 越智繁雄 - 安田吾郎 - 岡村次郎 - 青野正志 : 大 規模水害時における地下鉄等の浸水想定と被害軽減方策の 効果分析, 土木学会論文集 B1( 水工学), Vol.68, No.3, 136-147, 2012.

4) 関根正人・浅井晃一: 神田川流域を対象とした豪雨による 浸水・氾濫に関する数值予測, 土木学会論文集 B1 ( 水工学), Vol.71, No.4, I_1429-I_1434, 2015.

(2015. 9. 30 受付) 